\title{
Toward Hybridity: The Interplay of Technology, Pedagogy, and Content across Disciplines at a Small Liberal Arts College
}

\author{
Julie Rust \\ Millsaps College \\ rustje@millsaps.edu
}

\begin{abstract}
Through semi-structured interviews with sixteen faculty members representing a variety of experience levels and departments, this piece illuminates faculty theories and ideas about digital pedagogy through the conceptual lens of TPACK (Mishra \& Koebler, 2006), which delineates the overlapping considerations teachers in designing learning through technological knowledge, pedagogical knowledge, content knowledge. Findings reveal widespread similarities in attitudes toward teaching and learning across all different departments and indicate that, while faculty members had a range of content knowledge, pedagogical knowledge, and technological knowledge inferences, the greatest tensions and successes were articulated when faculty discussed issues located at the nexus of technological knowledge, content knowledge, and pedagogical knowledge.
\end{abstract}

What our college means in today's world is a very different thing than what it meant in a pre-digital media world ...

you went to college thinking about college as the smart phone... in [our state] there was one smartphone and if you could get into [our] College you would have access to it . . . and now you can access information everywhere but what you need is the ability to evaluate it ... [we have] an opportunity to get to what was always the crucial issue ....

[Faculty member, 2016, *Smith College, personal interview]

Upon my on-campus interview at *Smith College, the immense amount of green transported me to an entirely different era. Each classroom I visited featured a tight circle of no more than 10-15 thinkers, analyzing annotation-sprinkled paper texts with great fervor. "We don't use Powerpoints here," I was told by a newer faculty member by way of caution. "Our students aren't used to that kind of approach." My initiation into the culture of the small liberal arts college mirrors the complicated ethos that has been described on similar types of campuses (Spodark, 2003; Lohnes \& Kinzer 2007). Technologies are tolerated with a great deal of skepticism here, and the exploitation that the e-learning industry has wrought, the notion that there is an easier way to outsource teaching and learning is one that breeds much discontent in a space that privileges face-to-face discussion, small teacher to student ratios, and critical discourse.

However, now that I've spent four years as an assistant professor at *Smith, it has become increasingly apparent that, contrary to the popular monolithic belief described above about faculty on small liberal arts campuses such as mine, there is a wide spectrum of difference in the ways in which faculty utilize and relate with newer tools for teaching and learning. During my appointment as a Faculty Fellow, I sought to make sense of exactly how faculty across disciplines are reckoning with questions that are situated at the intersection of student learning objectives, pedagogy, and technology.

Through semi-structured interviews with sixteen faculty members representing a variety of experience levels (from 1 year to 36 years at the institution) and departments (across all three campus 
divisions: sciences, arts $\&$ humanities, and business), I capture faculty theories and ideas about digital pedagogy through the conceptual lens of TPACK (Mishra \& Koehler, 2006), which delineates the overlapping considerations teachers in designing learning through technological knowledge, pedagogical knowledge, content knowledge. Findings reveal widespread similarities in attitudes toward teaching and learning across all different departments and indicate that, while faculty members had a range of content knowledge, pedagogical knowledge, and technological knowledge inferences, the greatest tensions and successes were articulated when faculty discussed issues located at the nexus of technological knowledge, content knowledge, and pedagogical knowledge.

\section{Literature Review}

Work around technology integration in higher education abounds (e.g. Fairchild et al., 2016; Zhang, 2010). Additionally, a body of scholarship exists the aims, particularities, and future potential within liberal arts colleges (Umback \& Kuh, 2006; Clark, 1992; Breneman, 2010). In fact, Umbach \& Wawrzynski (2005) point out that faculty at liberal arts colleges are more likely than faculty at other types of higher education institutions to engage their students through more "active and collaborative learning techniques", experiential learning opportunities, higher-order cognitive tasks, and high quality faculty/student interactions (p. 155). Nevertheless, a host of obstacles block technology integration at small liberal arts university, including lack of clear vision, the absence of leadership, the unavailability of a critical mass of technology, absence of incentives, and inadequate faculty participation (Spodark, 2003). However, institutional failings are not the sole factor to blame. In this article, I qualitatively examine the teaching beliefs that inform faculty decision-making around technology integration in small liberal arts colleges.

\section{Faculty Beliefs \& Teaching Practice}

Despite the fact that teaching beliefs is a "messy construct" (Pajares, 1992), it is undeniable that that teaching practices emerge from a confluence of beliefs: beliefs about your students, your position as a teacher, the value of particular pedagogical approaches, the affordances/limitations of particular tools, and on and on. Pajares (1992), in fact, invokes Ernest (1989) and Nespor (1987) when arguing that affect-laden beliefs impact how a teacher teachers far more than knowledge of a particular discipline. Taylor (2003) points out that "some of the most critical barriers to change in educational processes are personal ones" (as cited in McQuiggan, 2007, p. 9). Perhaps one reason this is the case is because:

Beliefs have great value in dealing with complex, ill-defined situations such as those teachers tend to encounter, in which there are large amounts of information available and no single correct solution. In such contexts, the episodic and unbounded nature of beliefs makes it possible to apply them flexibly to new problems. Moreover, the nonconsensual nature of beliefs makes them relatively immune to contradiction. (Ertmer, 2005, p. 30)

It naturally follows that beliefs are also notoriously resistant to change, particularly those central to particular identity practices (Pajares, 1992; Ertmer; 2005; Rokeach, 1968). Faculty members are most likely to experience incongruity between their existing educational beliefs and their lived reality through personal experiences, vicarious experiences, and social-cultural influences (Ertmer, 2005). There is a clear need, then to examine "the messy process through which teachers struggle to 
negotiate a foreign and potentially disruptive innovation into their familiar environment" (Zhao, Pugh, Sheldon, and Byers, 2002; p. 483, as cited in Ertmer, 2005, p. 27)

Fairchild et al. (2016) examine this very process in their nuanced look into instructor "surprise and sense-making" when integrating technology into learning. Their series of interviews revealed three dialectical tensions: freedom vs. confinement; connectedness vs. fragmentation, and change vs. stability. In order to negotiate their way through these tensions, instructors utilized small-scale dayto-day adaptations (including an increased "tolerance for ambiguity") and larger-scale reframing practices (consisting of resistance, co-optation, or revision) (p. 103). This emphasis on a dance of both the macro and micro resonates with Zhang's (2010) insistence on a better understanding of learning cultures as complex systems with both macro-level elements (e.g. epistemological beliefs, power structures) and micro-level components (e.g. tools, activities). He contrasts this with more "reductionist, proceduralized" approaches attitudes toward teaching with technology which result in, rather than transformation, a domestication of newer tools to maintain the status quo (p. 1).

Ertmer \& Ottenbreit-Leftwich (2010) conceptualize two types of beliefs impacting the transformation teachers are willing to enact using new tools: self-efficacy beliefs and pedagogical beliefs. Self-efficacy (Bandura, 1986), or the way in which an individual views their "competence to execute a particular task - [is] the strongest [predictor] of human motivation and behavior" (Pajares, p. 328). Because shifting teaching tools/platforms has the potential to relocate an experienced instructor into a more novice position, faculty can report feeling "unsettled", "bewildered" or "overwhelmed" (McQuiggan, 2007, p. 9). Faculty that lack confidence in their own ability to teach with technology might benefit from time dedicated to playing with technology; a focus on starting with successful experiences; knowledgeable peers to work alongside; access to suitable models; professional learning communities; and situating any kind of professional development within teachers' current/ongoing work (Ertmer \& Ottenbreit-Leftwich , 2010, p. 262).

Pedagogical beliefs also play a central role, as Ertmer (2005) points out when she highlights Becker's (2000) finding that computers often serve transformative roles in instruction when teachers' personal beliefs resonate with constructivist pedagogies. Faculty also possess beliefs around the value of particular technologies for their purposes (Zhao, Pugh, Sheldon, \& Byers, 2002; as cited in Ertmer \& Ottenbreit-Leftwich, 2010). Beliefs about the cultural norms and expectations within a college/university also strongly impact professors' use of new media in learning. Somekh (2008) explains that 'Teachers are not 'free agents' and their use of ICT for teaching and learning depends on the interlocking cultural, social, and organizational contexts in which they live and work" (as cited in Ertmer \& Ottenbreit-Leftwich , 2010, p. 264 ).

In addition, faculty are often reacting to their perceptions of students' beliefs. While college students are active users of newer tools in dorm rooms and social spaces, they often experience reluctance when such tools are demanded in more formal learning environments (Lohnes \& Kinzer, 2007). Spodark (2003) interviewed several undergraduates at a liberal arts college and cited that their attitudes revolved around quite traditional models of teaching and learning in which the professor utilized physical classroom spaces to pour knowledge into students' minds. This synthesis of institutional, faculty, and student beliefs around technology produce ripples that reach far beyond the college classroom; in fact, they funnel largely into how college graduates go on to take up digital practices in their future professions (Brown \& Warshauer, 2006).

\section{Theoretical Framework: TPAC}

With the tangle of attitudes, histories, and competing perspectives that make up college classroom spaces, it is no small wonder that faculty ever make definitive decisions and transformations of practice. While the literature review above delves into the underlying beliefs that color the decisions Journal of the Scholarship of Teaching and Learning, Vol. 19, No. 2, March 2019. josotl.indiana.edu 
faculty make, Mishra \& Koehler's (2006) TPACK framework highlights the dance of various knowledge bases that inform the ways in which we design learning experiences with particular tools at our disposal: knowledge around technology, pedagogy, and content. I argue, however, that deeply-held beliefs (around teaching, learning, context, and your students) inherently infiltrate all conceptualizations of pedagogical, content, or technological knowledge.

Mishra \& Koehler (2006) well-recognize the incredibly "dynamic, ill-structured” environment in a classroom as well as the nuanced, non-neutral characteristics of the technologies utilized in these spaces (p. 1025). Their attempt to capture more of the complexity in teaching and learning with tools (beyond "what should I use" and moving toward "how should I use it?") is their introduction of the "TPACK model” (technological pedagogical content knowledge). (See Figure 1.)

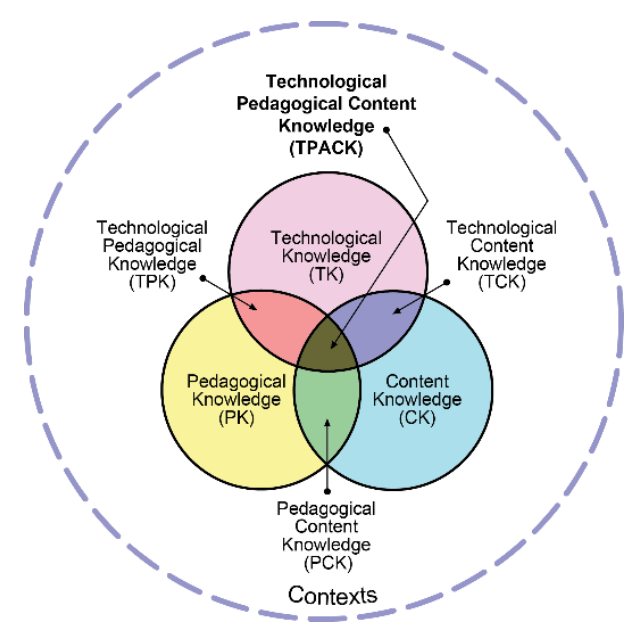

Figure 1: (Reproduced by permission of the publisher, (C) 2012 by tpack.org)

TPACK emphasizes the tangle of three separate but inter-related fields of content, pedagogy, and technology. Content knowledge signals the knowledge an instructor has about the actual subject matter being taught; for instance, a Biology professor's understanding of basic cell structure. Pedagogical knowledge, however, refers to the ways in which teaching and learning in a particular domain might emerge. For instance, a Biology professor may be influenced by constructivist epistemologies and might ask students to build their own cell structure using various provided candies. Technological knowledge, then, refers to knowledge about any tool used for teaching/learning purposes. In the case of our Biology professor, she may need to work an overhead projector to model how to do the activity. She may need to have knowledge about how sticky or flexible the candies are to ensure she has provided appropriate materials for construction.

Although these three processes have been artificially separated above, it is essential to understand that the three are always intermingling. Mishra \& Koehler (2006), in fact, clearly recognized the folly of trying to operate any other way:

Clearly, separating the three components (content, pedagogy, and technology) in our model is an analytic act and one that is difficult to tease out in practice. In actuality, these components exist in a state of dynamic equilibrium or, as the philosopher Kuhn (1977) said in a different context, in a state of "essential tension." The traditional view of the relationship between the three aspects argues that content drives most decisions; the pedagogical goals and technologies to be used follow from a choice of what to teach. However, things are rarely that clear cut, 
particularly when newer technologies are considered. The introduction of the Internet can be seen as an example of a technology whose arrival forced educators to think about core pedagogical issues (Peruski \& Mishra, 2004; Wallace, 2004). So, in this context, it is the technology that drives the kinds of decisions that we make about content and pedagogy. (p. 1029)

So when a faculty member makes any course-related decision, she is necessarily drawing on all three knowledge sources (technological pedagogical content knowledge.) At particular moments, however, one piece may be foregrounded. For instance, as I first set up my video reflection platform for students I had to initially focus in on my technological knowledge just to add their accounts to my account. Then, as I began to type out the assignment sheet I had to think carefully about my pedagogical approach to best enable them to engage with the material. Then, as I responded to their video blogs I began to centralize my attention on my content knowledge about best practices in teaching literacy.

Mishra and Koehler advocate for instructor reflection at the levels of pedagogical content knowledge (PCK), technological content knowledge (TCK) and technological pedagogical knowledge (TPK). What teaching methods might work best with this particular content? What technologies might best enable students to project content mastery? What tool might work best for this teaching idea? Mishra \& Koehler (2006) offer TPACK as a model that is greater than the sum of its parts:

Thus, our model of technology integration in teaching and learning argues that developing good content requires a thoughtful interweaving of all three key sources of knowledge: technology, pedagogy, and content. The core of our argument is that there is no single technological solution that applies for every teacher, every course, or every view of teaching. Quality teaching requires developing a nuanced understanding of the complex relationships between technology, content, and pedagogy, and using this understanding to develop appropriate, context-specific strategies and representations. (p. 1029)

TPACK has spread like wildfire among teacher education circles but has done less to impact other fields in high education (Angeli et al., 2016). I use TPACK in this study as a grounding framework for the issues around teaching with technology that faculty members raised during interviews. Tracing whether an instructor's beliefs around teaching with new media resulted from a question of pedagogical knowledge, content knowledge, technology knowledge, or an interplay of multiple components enabled me to analyze the efficacy of the framework for making sense of patterns emerging from my own institution's norms and attitudes as we discussed teaching and new media across a range of disciplines.

\section{Methodology}

During the Spring semester of 2016, I launched an inquiry as part of my work as a Frueauff Digital Pedagogy Fellow in designing faculty development opportunities for the Fall of 2016. It quickly became apparent that my informal conversations with a range of faculty members across disciplines provided deep insight into lingering questions around teaching with technology in higher education, and I formalized my work into a study in order to bring light to the following questions (See Figure 2.) 


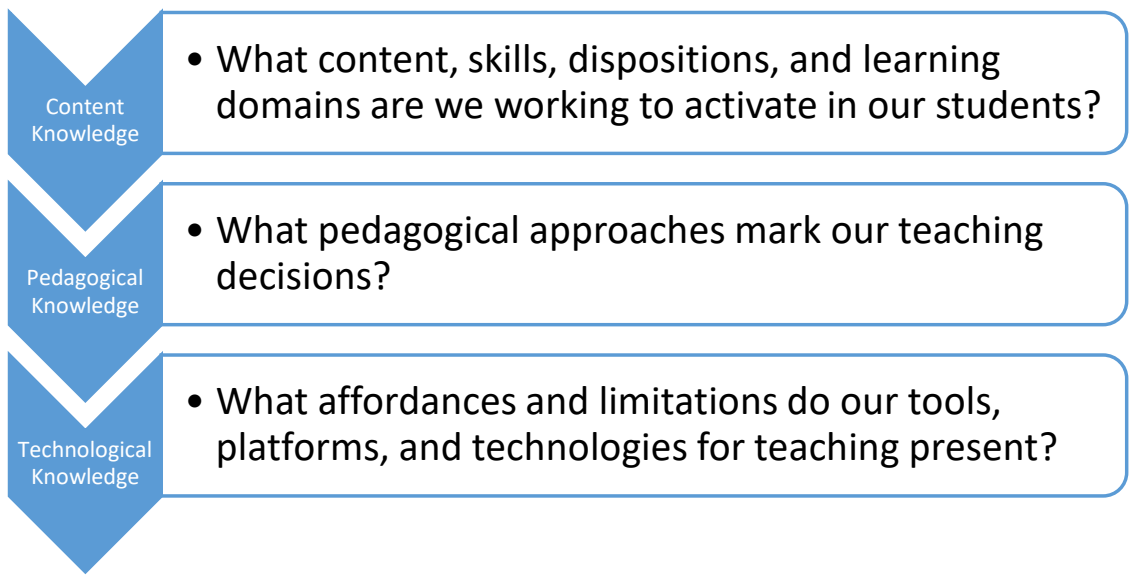

Figure 2: Research Questions Mapped On To TPACK Triad

\section{Context}

The study took place at a small liberal arts college (with around 850 students) located in a metropolitan area in the Deep South. Notably, the college had recently adopted a new curriculum, which focuses around four Student Learning Outcomes (referred to as SLO's): Problem Solving \& Creative Practice, Communication, Thinking \& Reasoning, and Integrative \& Collaborative Learning. The faculty at *Smith are, from my estimation, unusually close-knit due to the size of the college and the fact that it is known as a fairly liberal institution in the heart of a very conservative state. The mission statement of the institution is linked to social justice "across the street and around the globe". There is a huge emphasis on teaching quality among faculty and administration, as illustrated by the heavy emphasis on professor evaluation scores in the Tenure and Promotion Process and the amount of opportunities/support provided for pedagogical inquiry and advancement.

\section{Participants \& Data Sources}

I first emailed a purposeful sample of tenure-track faculty members with the explicit aim to include a wide range of disciplines (professors from the business school, sciences, and arts/humanities) as well as varied pool of experience levels (beginning, mid, and end of career). I specifically targeted this sample in order to get a full account of the ways in which faculty across different fields and ages/years of experiences were making sense of their technological pedagogical choices. I received a reply and consent to interview from sixteen faculty participants spanning fourteen different departments across campus. (See Table 1 for details). The mean of years of experience at the college was 12.38 years.

\begin{tabular}{|l|l|l|l|}
\hline Participant & Department & Division & Years at College \\
\hline 1 & Education & Sciences & 36 \\
\hline 2 & Philosophy & Arts and Humanities & 30 \\
\hline 3 & Philosophy & Arts and Humanities & 30 \\
\hline 4 & Religious Studies & Arts and Humanities & 20 \\
\hline 5 & Theater & Arts and Humanities & 2 \\
\hline 6 & Biology & Sciences & 2 \\
\hline 7 & Art (Studio) & Arts and Humanities & 2 \\
\hline 8 & Art (History) & Arts and Humanities & 26 \\
\hline 9 & Economics & Business & 14 \\
\hline
\end{tabular}

Journal of the Scholarship of Teaching and Learning, Vol. 19, No. 2, March 2019.

josotl.indiana.edu 


\begin{tabular}{|l|l|l|l|}
\hline 10 & Political Science & Sciences & 2 \\
\hline 11 & History & Arts and Humanities & 14 \\
\hline 12 & Physics & Sciences & 7 \\
\hline 13 & Math & Sciences & 5 \\
\hline 14 & Anthropology & Sciences & 14 \\
\hline 15 & English & Arts and Humanities & 1 \\
\hline 16 & Psychology & Sciences & 3 \\
\hline
\end{tabular}

Table 1: Study Participants

Each digitally-audio-recorded 30-45 minute semi-structured interview was conducted much more like an informal conversation rather than a strictly-business pursuit. (See Appendix A for sample questions.) Conversation topics ranged from sharing life stories ("here is why I became a professor") to areas of dissatisfaction with our institution to laughter and joking. It is important to note that at the time of this study I was keenly aware of my status as a second-year Assistant Professor and engaged in these conversations in the way an anthropologist may seek to make sense of a new community. In other words, there were no "right answers" I was searching for to signal the best pedagogue, and I did as much work as I could to reassure faculty members that my inquiry was in no way evaluative. I also had a research student accompanying me to several interviews and he did conduct one interview completely on his own.

\section{Analytical Methods}

After transcribing the sixteen interviews, I began to engage in discourse analysis (Gee, 2011) to make sense of how faculty language produced specific socially situated teaching identities, or how each faculty member constructed their practices as a particular "who-doing-what" (Gee, 2011, p. 30). I initially sorted faculty utterances into three separate a priori code buckets that emerge from the TPACK framework (Mishra \& Koehler, 2006) introduced above: foregrounding content, foregrounding pedagogy, or foregrounding technology. Once the initial data dump was concluded, I engaged in emergent, open coding practice (Saldana, 2015) to find sub-components for each large category. Some code labels were derived in vivo (Corbin \& Strauss; 2008), such as when one psychology professor talked about her discipline as providing tools for everyday living when she called psychology a "toolkit for doing life". This phrase became a code under the larger bucket of "foregrounding content" which emerged as a theme across multiple interviews. Other codes emerged more generically; for instance whenever a faculty member talked about collaborative pedagogy I put the transcript unit under the larger bucket of "foregrounding pedagogy" with the code "collaboration".

Because I was quite interested in patterns across disciplines and repeating attitudes/ideas around these issues I also indicated a count beside each theme that emerged. Note that the count doesn't indicate the number of utterances, but rather indicates the number of faculty whose language pointed to the same code. For example, if a biology professor mentioned using hands-on experiences for content acquisition and a theater professor mentioned using improvisational drama games both might be coded for "active learning practices" and the category would be labeled with a number 2 .

I then noted two attitudinal poles that emerged in conversations: "general optimism about new tools" or "pessimism about new tools". It quickly became apparent that these moments of positive or negative judgment generally arose when faculty were articulating the interplay between pedagogy, content, and technology in their reflections. The findings section below shares highlights 
from the three main research questions and then ends with an examination of faculty's perceived limitations and barriers around the integration of new tools for teaching and learning.

\section{Findings}

\section{RQ 1: What content, skills, dispositions, and learning domains are we working to activate in our students?}

Unsurprisingly, faculty had a range of $21^{\text {st }}$ century discipline-specific goals that drove their teaching practices. For instance, a faculty member in the education department discussed the need to increase teacher candidates' familiarity with technology tools that their future K-12 school settings might employ (e.g. Smart Boards, iPads, etc.) A mathematics professor saw her role to provide a theoretical background to empower future professionals in whatever application goals they may wish to achieve. A studio art professor works to enable students to "draw digitally, edit photos, make photos, and present work online professionally." A faculty member in physics spoke at length about the importance of "numeracy" and inspiring students to "play with" numbers. A business management professor emphasized student learning objectives around big data analysis and interpretation, explaining, "I focus on interpretation and that is because when those people go to work, nobody's going to say 'here's a pile of data, what's $r$ squared?' they are going to say 'what does this mean'?"

Notice that while the business faculty member began her thoughts squarely in her disciplinary content area ("what's $r$ squared?"), she didn't stay there long ("what does this mean?"). Again and again, my interviews with faculty broadened my understanding of content knowledge, and reaffirmed the miles of common ground that professors from math to business to English seek to cover. Professors emphasized competencies, skills, and dispositions far more often than they emphasized content coverage. For instance, a physics professor discussed one key goal: "[the] life skill, of taking responsibility for their own learning. You know . . that's not a discipline-specific thing in any way, but when they view my role as someone that's there to assist them, mentor them, nudge them in the right direction; those students matter, they make a difference, they go really far."

Unsurprisingly, much of this common ground revolved around a new general curriculum the campus had recently created and voted on, which included the following student learning outcomes: integrative learning, collaboration, problem solving, creativity, critical/analytical thinking, and communication. (See Figure 2). This move to larger competencies is described by one biology faculty member as far more effective:

For me, it's the core competency stuff- the critical thinking... I may not teach you every step in a pathway ... so it's more important to me that they're able to make connections to this pathway over here and this pathway this other cell uses and overall they're doing the same thing in slightly different ways because the cell needs energy. Big picture more important than specific content ... We can only focus on so much specific content. . . We cannot tailor one person's education to exactly what they want to do. . competencies rather than the content.

The difficulty in cultivating generative collaboration in undergraduates came up in nearly all interviews, but only two specifically mentioned it as central to their mission. A philosophy professor explains its centrality:

To be honest, we sort of cultivated the loner scholar for a long long time at [the college] and now we're moving in a better direction in my opinion . . . collaboration . . . knowledge is not a solitary Cartesian reflective thing, it's something we collaborate upon ... we corroborate one another's claims and if we can't do that than we're in trouble basically . . . if I can't hold it up 
for rational inspection and say what do ya'll think and not be pissed about it when I get a thumb's down, than I'm in sorry shape ... and students too.

Collaboration at $*$ Smith College is not only important in theory. It is part of the new curriculum recently created and adopted by faculty. As one of the student learning outcomes (SLO's), it has become part of the underlying point of the school. Figure 3 lists all of the new SLO's in order of the number of faculty who mentioned them by name during an interview.

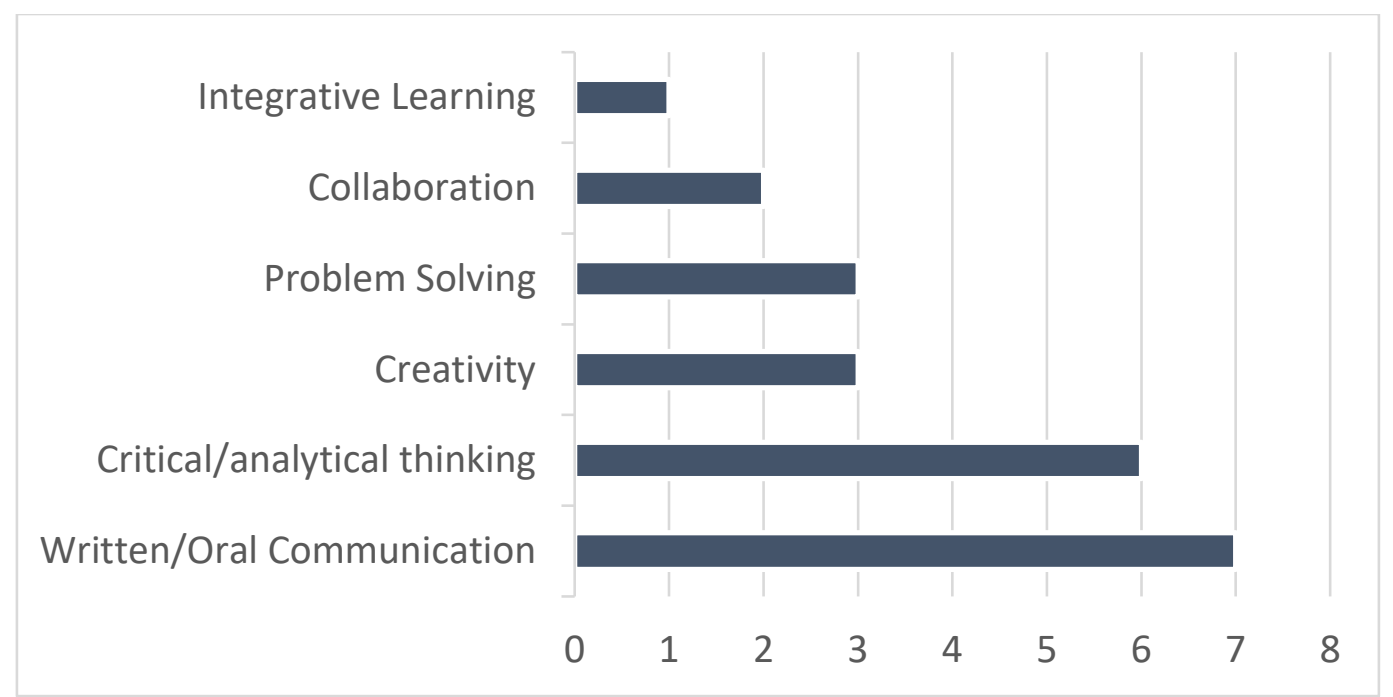

Figure 3. Student Learning Outcomes Emphasized by Faculty Members

It is obvious from Figure 3 that communication practices organically emerged from faculty interviews most often. The business professor explained the linkages between content knowledge and this larger SLO this way:

So you've got this is minimum wage over time, this is unemployment over time to what itat that level it is more, can you plot this? And then can you describe what you see in what you find? So if you are listening to NPR on the way to work this morning and, and the listener only knows what is told to them. So can you describe this data in a way that the reader driving in or the listener driving into work could understand the main points?

Of course, the type of communicative practices privileged varies widely across disciplines represented. While from a business standpoint data interpretation is key, a political science professor described communication as public speaking skills, a set of abilities that he recalled from working in government and political campaigns that many young people lacked. For one first year English professor, poetry took center stage in meaning-making:

I hope to convince [students] to see poetry as an operating system. Just like when you, you go to the ... Office Depot and get your new laptop ... you have choices to make. And, and it's not like in some sort of absolute sense your Windows system is any worse than your, than your Apple system or vice versa . . . they help you different things. And so, the operating system that I would hope to instill to my students, or pass onto them, is one that sees these formed patterned slices of language as resonate for their life experiences outside our classroom. 
Again and again, faculty, like the one quoted above, alluded to the application of their course material and experiences to a larger arena ... life. Figure 4 represents the various ways that faculty viewed their work with students as larger than merely disciplinary content acquisition.

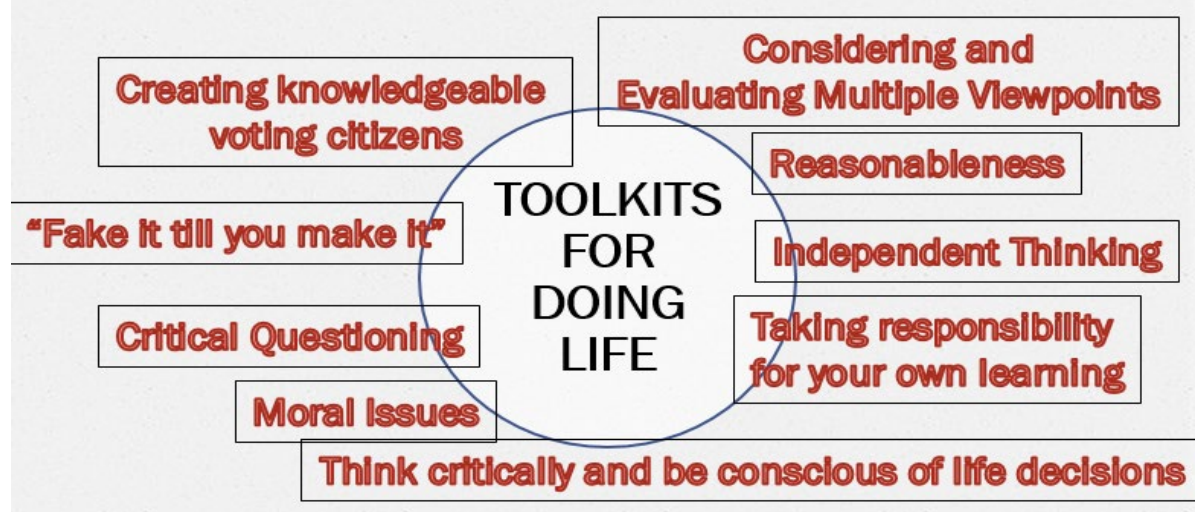

Figure 4. Toolkits for Doing Life

Twelve out of the sixteen interviewees spoke at extended length and explicitness about life application when asked about their objectives for their course. One psychology professor explained:

My main goal for them to take away is the fact that psychology is a very useful tool for looking at the world and I try to explain to my students that I see psychology everywhere. . When I'm interacting with my friends and they tell me problems, I see psychology. When I'm watching TV, when I'm reading books, when I'm seeing a movie, when I'm angry with people, when I'm whatever it is and I'm trying to plan out for my future I see psychology. And I can use psychology terms and theories to help explain my behavior and influence my behavior and then I can use it for other purposes and I think that's a really unique aspect of the discipline . .. Psychology is so fun because people don't know that they're doing it and people don't know that they're using the skills. So really I look at it as an awakening ...

While the psychology professor saw her discipline as unique in its life-application-reach, her sentiment was far from unique. Faculty members from philosophy to physics spoke of the particular toolkits for richer lives that their discipline offered. One theater professor in his second year at the college described the central performance-linked disposition he sought to cultivate in his students: "fake it "til you make it":

For me, students write less because they're less comfortable with that aspect of performing because no matter what you say ... it's a performance. And they don't start because they second guess themselves. 100\% of the time second guessing is what stops you from writing a paper. Of any kind. Or a poem. Or a short story. Or a project proposal. You just feel on 
the spot and say 'I've got nothing' ... For lack of a better word I really think it's fake it till you make it.

For this professor, "being able to produce your best work on the spot when it really matters when everybody's listening and everybody's turning to you" is not merely about acting on the stage. It is the spontaneous, ever-emergent improvisation that millions of small and large life situations demand.

Faculty members also honed in on the way that their work with students might empower critical questioning, independent thinking, and consideration/evaluation of multiple viewpoints. A philosophy professor in his thirtieth year at the college labeled this as an orientation of reasonableness that the entire college experience coalesced to create:

When students are good examples of the *Smith College product (I really dislike the idea that I'm instilling virtues) but still, there's a type that you see ... not just their skills but their whole orientation went through a paradigm shift of sorts. There's this thing that they get about how to be a thoughtful responsible human being and here's the rough part about it- it separates them from a lot of people around them. They'll come back to us and say "it's not *Smith College out there" in the business world or the government agency or the doctor's office ... but the good news of course it that [our state] is peppered with people who went to *Smith College who have that different outlook ... so reasonableness would be the one word.

Reasonableness, as a tool for life, comes in handy for a variety of situations, but one biology professor zoomed in on its import for citizens participating in a democracy. For her, the ability to vote responsibly goes beyond pure reasoning capability and ventures into the knowledge domain:

We need a bioethics and biotechnologies course because these are the types of things as citizens that are going to be coming up in voting and there's a lack of scientific expertise in Washington that is troublesome ... if people understood the issues they'd be more informed voters or law-makers.

Being informed, of course, isn't just useful in citizenry issues; knowledge illuminates personal decisions as well. One psychology professor emphasized:

When I'm teaching my Adulthood and Aging class, one of my main goals is I want them not to be scared of aging. I want them to understand that aging is a normal and wonderful part of our development that you really want ... the alternative is you die now and you don't age and then you don't go through it . . But I also want them to be thinking about end of life choices really critically ... I want us to be thinking about is it really that important that we are expanding our lifespan if that means a reduced quality of life? I mean, do we want to be able to have choices about what control do we have over our own medical care and when and where we die? ... Those are the sorts of questions that are really uncomfortable but I think they're incredibly important . . . So I try to hopefully have them think more critically about things that they're going to be experiencing later on and begin to be conscious of their choices.

Although Mishra \& Koehler's (2006) framework conceptualizes teaching decisions as originating from a complex negotiation of content knowledge, pedagogical knowledge, and technological knowledge, it is clear from my conversations with faculty that the phrase "content knowledge" fails to capture the breadth, depth, and width of the goals that instructors have for their Journal of the Scholarship of Teaching and Learning, Vol. 19, No. 2, March 2019. josotl.indiana.edu 
students at *Smith College. Backwards design asks us to "begin with the end in mind"; these conversations with faculty at $*$ Smith College about pedagogical design requires a very broad net to make space for these larger, less discipline-specific non-negotiables. Faculty can name and claim these objectives, which contain an array of discipline specific content (e.g. "what is constructivist theory"), competency-centered skills (e.g. "students will exhibit creativity by reflectively adapting their lesson plans in-the-moment"), and life tools or dispositions (e.g. "students will learn resilience in the face of obstacles"). Once these focal goals and objectives have been named, faculty move into far more thorny territory: how to actually go about teaching in a way that moves students in these predetermined directions.

RQ 2: What pedagogical approaches mark our teaching decisions?

As a teaching institution, it is perhaps not surprising that *Smith College draws faculty that take quite seriously their roles as teachers. A studio art professor explained the reward that gaining trust with progressing students triggers and went on to say:

The Internet is this amazing tool and it makes me think- do we need teachers anymore? We very clearly need teachers to funnel energy and to direct energy; we need teachers to be a personal [touchstone] for these students. The Internet works once you have some kind of a framework for using it.

Pedagogical knowledge reveals deep understanding of both our students and our role as teacher, an instinct about exactly how to funnel that learning energy within the affordances and constraints of classes and institutions and formal learning contexts. A comprehensive list of pedagogical moves that were described during interviews, along with the number of interviewed faculty that named them, can be viewed below, and I choose several key themes to discuss more in depth in this section.

- Active, varied teaching and learning strategies (5)

- Student-Led, Student-Centered, Dialogic (5)

- Talking about technology as it emerges in discipline (4)

- Hands-on, experiential, applied learning (3)

- Use of Storytelling/Narrative (3)

- Empower student voice (Improvisation, Oral Presentations, Stand and Deliver, etc.) (3)

- Reflection on what does and doesn't work (3)

- Open-ended prompts

- Inclusion of under-represented voices

- Limiting materials and media

- Hone own teaching persona

- Push playful problem-solving

- Flipped Classroom

- Getting Interdisciplinary

- First master tool, then move to ideas 
Pedagogical design can be experienced as a deeply personal, anecdotal, choose-your-ownadventure. It can also be characterized as a generalizable set of research-based best practices. For our physics professor, it is clearly the latter:

And so, you know, I think what I would like for us to see is a way that_-I'm not interested in what I want to do, or what I think works; there's been tons of research on what works. Let's do that. I don't care, I don't care if it's comfortable for you or not, I don't care if you think it's this or that. If you've got 10,000, you know, data points that clearly show this works and what I'm doing doesn't. It's you know standing there, talking, chalk in my hands, making the students laugh, telling funny stories about Michael Faraday ... they love it, they give me a 6.3's [out of a score of 7 on student evaluations], I get promoted to full professor, they don't learn a damn thing, right? 'They learn that, that Michael Faraday was weak at math; that's something a lot of them might could take away, is that one of the most important scientists ever was very, very weak at math ... how often are you doing these things in your class that work? If you're doing those things, you're fine. Your students may hate it, your students may like it, but it works.

It was clear from the previous section that "determining what works" can be more complicated than giving students a test to see who has mastered the content; faculty objectives spanned much broader territory than simply content knowledge. For our studio art professor, good pedagogy calls for prompts that are open-ended and demand student interpretation:

So in my prompts I do leave a huge amount of room for interpretation ... I tell you how to use the tools and what they are for and the things I think are most important for making a good-looking image, but not "what should it consist of" because in art there is no definition like that. Art is about communication, expressions, it's not about rules. . . For my Photoshop conceptual project [I simply ask students to] show me a story, use Photoshop to tell your story. .. [Students in] my sculpture class [say] "if you could just TELL me what to make, I will make it." NO. I won't do that. There are some art professors who have a diff philosophymake what I make, do what I do, they're working for me! And that's completely opposite my philosophy because I am so bored of myself . . . it would be so- unhelpful.

This open-endedness can be a challenge for students. A physics professor described it as playful problem solving:

And one of the things I will do this with the students from time to time-is I give them, you know, to see how numbers connect to each other in the same way. . . At some point they will learn the light from the sun takes eight minutes to get here. Right? Eight and a quarter minutes. If you know one semester of physics and the speed of light (which essentially every physics student after one semester or two semesters should have that number petty close to memorized) you can now calculate the mass of the sun.

Just as in art, students might create a conceptual Photoshop project, and in physics students might be asked to connect significant numbers to calculate the mass of the sun, students in philosophy, political science, or anthropology might be asked to engage in open-ended meaning-making through the vehicle of dialogic discussion. One philosophy professor explained: "the wonderful class is when students are talking to each other and you don't have to be continually nudging or guiding." Several Journal of the Scholarship of Teaching and Learning, Vol. 19, No. 2, March 2019. josotl.indiana.edu 
professors, in fact, described making large changes in their class based on student push and ownership over the content. A political science faculty member explained:

A student actually wrote his research paper on Obama's use of social media, looking at Tweets and Facebook primarily and made me realize next time, this is the ideal use of this ... the governing end not the campaigning end. I would like to look at how politicians or elected officials who are of different generations look at this . . . but I have not done enough of this in class and I think I will in the future, especially with public administration, because that's the best place to look.

This same push to carve out class experiences that ask students to create, to find their own voice, is echoed in the theater professor's interest in what he calls "stand and deliver pedagogy". I'm really interested in students finding their voice . . . I would like to see more stand and deliver pedagogy where someone's on their feet with no bullshit device or even a piece of paper to read off of but being on the spot. .. It's the fake it till you make it ... We have the best time celebrating the fact that we know nothing. It's the very fact of honoring your own voice.

He went on to describe a common classroom practice of asking students to ad lib answers onthe-spot to questions of which they had no way of knowing the answers:

Improvisation is my favorite . . the main tenant is that idea you have in your idea that you think is stupid, you need to put it on paper or you need to speak that word right away. Number one: It's probably not as stupid as you thought. Number two: It's only the first thing you are saying or writing. It's not etched in steel and erected in the middle of campus.

Many of these improvisation exercises that the theater professor utilizes demand movement and spaces beyond the four walls of a classroom, which pedagogically afforded multiple benefits, not the least of which included attention-maintenance of students:

That's what great about theater... I haven't had to tell anyone to turn off their phone because we move all the time ... like they would literally run into the wall and it's fantastic. I think we have to change the conventions of our classrooms. I'm a big believer in changing the location a lot inside a class, changing where you sit, changing where the whole class is I mean there are things you can do, studies show, everyone's happier about it. But we get stuck in a rut.

For him, risk is a foundational component of learning, and when I asked him what the most "cutting-edge" theater folks are up to with their students, he didn't hesitate:

What's cool is what we're doing! We can devise pieces with faculty, students, cafeteria staffwe call this "devised"- when you get a room full of people and say Let's make a play so everyone writes it, everyone directs it, everyone acts it out, so NO MORE FUCKING EXPERTS. Everyone thinks in theater they can be really risky ... "bring this risky playwright from NY" you already blew it you're not taking a risk at all the risky thing you can do is put the students in charge that's it. That's your risk. But you don't want to do it because you're afraid you'll look bad. . . that's POWER. That's risk that pays off. 
He wasn't the only faculty member who emphasized risk. Three different professors talked at length of the strength of integrating partnerships with community-engaged-learning opportunities which enabled students to link learning in the classroom with reality. An education professor who had been at the college for thirty-six years described risk as something that faculty must take in developing and engaging in these partnerships:

I think I'm beginning to see faculty teaching differently . . . hands on learning is really important, student engagement is really important, we're seeing our faculty take students on field trips, things that are outside the gates of the college and really learning to use our community as a resource which is exciting ... it's great for professors to take risks, because that's what we want our students to do.

While not all faculty members described such consistent and radical movement during the course of a class, the most common pedagogical theme that emerged revolved around active learning practices. A math professor explained: "I'll have them get up- flipping coins or counting Reese's Pieces, getting proportions, doing scatter plots or dot plots on the board ... I do things like that to try to keep them engaged."

She went on to describe the importance of being responsive in terms of student needs throughout the lesson. In the case of noticing drooping or distracted students, she explained: "I'll stop [and] this might not seem pedagogically sound, [but I'll say] 'do you want to know a funny story about the kids?' just to get them back together." 'This tactic functioned well for students to take a break and refocus, but also afforded the side benefit of personally connecting with students.

In fact, four different faculty members mentioned the centrality of storytelling and narrative, often used in concert with the content of the course. One physics professor lamented that the only part he missed about lecturing when flipping the classroom was his insertion of historical antidotes about key physicists and engineers. A member of the art department faculty discussed the power of visual narrative, and an anthropology professor discussed the examination of games as narratives.

Situating content in the real world was also a strategic move described by the professors, one that sometimes resulted in shifting course topics and texts. A biology professor described the popular push (one she subscribed to) to begin re-naming and re-focusing generalized courses, such as "Cell Biology", into specific angles with specific contexts, such as "Marine Biology". She also described the importance of applying science content to big attention-getting questions. For instance, after discussing content in a traditional chapter in a biology textbook, students then might be asked to read articles such as "Growing meat in a test tube: Would you eat it?" She would then pose a key question to students: "Knowing what you now know, does it change your attitude on this question?" In other words, she is committed to teaching the "same basic concepts but putting them in the lens that is better for students that need to see why they need to know these things."

She is also keenly aware that each "non-major" in her science classes needs a different entry point into her content:

For my business majors, I would try to give them hypotheticals about experiments they might do ... so focus group testing if you want to know if college students will want a new cookie, because the concepts in setting up an experiment are universal whether you're talking about microbes or college students and cookies.

Perhaps because of this fact, several professors note a definitive interdisciplinary turn in their work with students in terms of content. A philosophy professor explained: "It's okay to be interdisciplinary ... In all classes, application sends them to other fields." Of course, weaving in Journal of the Scholarship of Teaching and Learning, Vol. 19, No. 2, March 2019. josotl.indiana.edu 
theories and applications outside of your training and expertise has its own challenges. One physics professor explained:

So I could definitely spend more time on the more current events stuff I could do- the theory of why that computer stuff is possible. The social- the whole hacking the cell phone, but that's really interesting but that's not the math, that's the ethical. I can talk about those things, but that's not really my discipline. I could talk about voting, how we count, we use plurality but we could rank the three people, etc. I would just be teaching them the techniques, not pursuing this open ended questions ... just to have something else that's more current- what's the best fit? It has to be an application I think because when you're back in the theory you're in the theory- but is it cryptography? Is it statistics?

Finally, the most notable of themes in these discussions around pedagogy were the deeply reflective ways in which faculty members considered what worked, what didn't, and the various institutional constraints and affordances within which they were working. One professor spent several minutes considering various ways to improve the current version of a class, alluding to extensive notes he takes during the course of each semester: "I'm struggling so badly with that class. I don't feel like I lit any fires under anyone. But when you get down to the nuts and bolts, it gets super tedious. While the overarching ideas was interesting, what they were doing was rather boring, but starting out from scratch sounds awfully daunting." It was the indecisiveness, the inner wrestling that I found most compelling in the course of these interviews.

\section{RQ 3: What affordances and limitations do our tools, platforms, and technologies for teaching present?}

Faculty members had a broad understanding of "what counts" as technologies for learning, from chalk to Internet. A history professor explained:

Well I define technologies of course broadly. I like to use technologies that I think are appropriate for the task at hand. So there are times when chalk and chalkboard are my technologies of choice; sometimes I like to have students write. I like to use PowerPoint in accordance with my lectures quite often, especially when visual imagery is especially important to the topic. When we do discussion work or in class research projects, I sometimes have my students use their own laptops and we do on the spot research questions. I require my students, beyond the 2000 level to do research at the archives and that can be done online, but then some of it is old fashioned going to the archives where they don't allow technology into the reading room. To sum that up, I try to use a range of technologies as they suit the task at hand. 


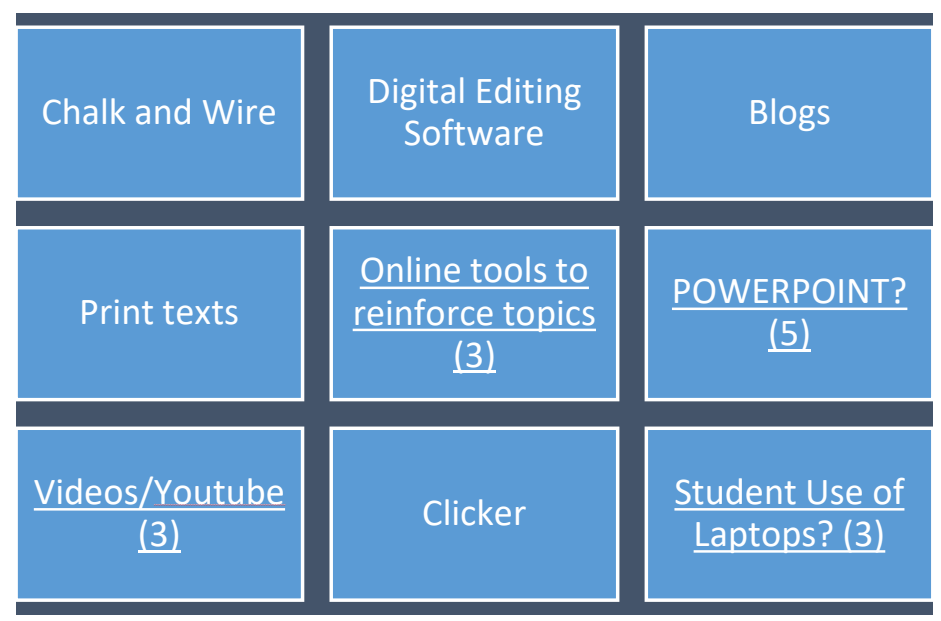

Figure 5. Tools mentioned by Faculty

Throughout the interviews, faculty members alluded to employing a range of tools to fit their purposes and goals (see Figure 5): a new campus-wide-adopted platform (Chalk and Wire) that facilitates portfolio building, digital editing software for art projects, traditional print texts (which several faculty insisted students prefer over e-texts), blog platforms for public sharing of ideas, or clickers for in-the-moment formative assessment feedback. Multiple faculty members discussed the ways that online sources of information can reinforce their course content, such as this business professor:

I assign the text but I also, frankly, assign sort of an either/or: you can either read the text or you can go to Khan Academy. . Some of them do both but, but those but, some of them really like the reinforcement of having to plot the graphs, shift the curves, and you can see the steps rather than-just the textbook, it all sort of appears there in front of you and you don't know where, where those graphs come from.

While the faculty member above allowed student choice in the source of their meaningmaking, an art professor detailed the student pushback she received when requiring the use of online tutorials: "I mean I do use online tutorials and I get some blow back for that and I think I've been working really hard to make them understand WHY I have those, because some of my early - and it's partly my fault for not introducing them as such, as a textbook ... " Clearly in her experience, her undergraduates didn't view online tutorials as a legitimate source of knowledge.

Increasingly, YouTube content and other video clips emerged across all disciplines. A political science professor, for instance, commonly will show clips of political ads to engage in analysis with students. One history faculty member discussed so in less-than-sanguine terms, as more of a "giving in" to the demands of her students.

I have shifted what I do. I show more videos. I present information in shorter pieces. I have them do shorter readings. I have students make use of technology that they've already gravitated towards, but I'm not always happy with that compromise. I have conceded some room away from books and to online video work.

A psychology professor, however, rather than viewing these video sources lens of deficit, saw them as burgeoning with possibility: 
So I do that, I do intersperse lots of clips from YouTube. I love doing that and I love being able to give examples, some classes are better or some lecture topics are more applicable with things like that ... so it's really great like when I'm talking I have this wonderful video for enjoying attention in my child development class that I showed last week. So it shows a neurotypical child enjoying attention I think they're like 14 months, a child who has Down's Syndrome, and a child who has Autism. So you can see how are these things show that "enjoying attention" and why do we think it's an important milestone we should be considering.

She also describes the art of documentary as essential in opening up perspectives. Here she was discussing how she shows her students How to Die in Oregon, a documentary that explores a range of end-of-life decisions by following a few terminal patients through their decision-making processes to the very end.

It's very upsetting to them and it's very upsetting to me. . . but I think it's really important to be able to see this other perspective because we are growing up in this super conservative part of the country and they probably have never thought of this and they probably haven't seen very human examples of this before... We have this whole conception that there is something noble in suffering, and I don't agree with that and I don't think psychology as a field agrees with that.

Interestingly, faculty found themselves quite divided in two main areas: the use of PowerPoint presentations in teaching and students' use of laptops in class. A political science professor describes his evolution here:

I have been going to great lengths to phase out things like PowerPoint. I'm using it when I have charts, graphs, pictures. When I started teaching as an adjunct, I was quite reliant on that because you feel like you're told you have to be and I can tell you from my own experience, the more I use that kind of stuff, the less engaged students are in things like discussions. And I think they read less because they expect whatever appears on that screen is all they need to know and they don't do as much work outside of the classroom.

On the other hand, a psychology professor points out the problem is not on Power Point usage itself, but how overly-reliant users might be on it:

I do use PowerPoints, and I know that's a little bit controversial at [*Smith College] because ... [when] I was in my orientation. . . somebody in it said "You're going to get terrible evaluations if you use PowerPoint . . students don't like PowerPoints." Right- if you don't understand how to use them appropriately! .. . So I definitely use PowerPoints. My slides are purposefully sparse and my expectation is you write them down and then you listen to the examples I give or you listen to the discussion prompts. I use them mainly a guide for myself to keep me on track. Mostly it's just because I need some sort of guide, some sort of structure...

Note the allusion above to the incompatibility of a particular technology with the culture of the college. The same theme arose when discussing whether or not students should be encouraged or even allowed to use laptops while in class. A first year professor in the English department explained:

Journal of the Scholarship of Teaching and Learning, Vol. 19, No. 2, March 2019.

josotl.indiana.edu 
Well for me it's really been about the culture of pedagogy on campus. I think that a lot of teachers that students respect have no-laptop policies, and it's been important for me to, you know, to try to cater to and play to the expectations of the student community here. And the culture of teaching here .. . There's a kind of very understandable, and in some ways a resistance that I appreciate and agree with, has shaded into the way that the students haveconceive of their education and the act of classroom instruction. No one complains when I say 'hey you can bring your laptops,' but you know, I think that there is kind of a sense that that is the way that, you know, [it isn't done?].

Interestingly, the faculty member prefaced this conversation with a discussion of his generative work in digital humanities. While teaching in graduate school, he would gladly invite students to bring laptops to class. Now situated in the context of a small liberal arts college like *Smith, he felt enculturated into a different set of pedagogical tool norms and affiliations. It is also important to note variations, however. For instance, a professor of education in her $36^{\text {th }}$ year at the college explained quite clearly that she saw laptops in class as a distinct advantage for sharing and looking up information quickly as questions arose during class. She explained:

Professors have told me that they walk around in class and look at the screens, but that feels like policing to me and I don't want to go there. . . But I have found that when [student in the room] uses his laptop, it's very helpful to me and to the rest of the class ... a responsible use of technology.

Another faculty member described losing patience with those so reluctant to incorporate newer tools for teaching and learning:

Those kinds of things are not cutting edge anymore, it's what our students should know how to access and should know how to do. I don't even know what is cutting edge. You know, I am not an early adopter, I'm sort of a midway adopter. I'm not going to be the first one to adopt some new technology, because I want to know that it works. But nor am I a dinosaur that doesn't ever do any of that stuff. It's sort of hard to teach students when they are. And students are using these tools, then I need to use them as well.

\section{Barriers Integrating New Tools}

The faculty interview excerpts above illustrate that many faculty are deliberately implementing a range of tools, both old and new, as they go about their pedagogical and content pursuits. However, faculty also articulated a range of challenges and limitations that digital tools surface in college classrooms. In this section, I unpack some of the most resounding themes that emerged (see Figure 6), including a lack of support in utilizing newer tools and the perception of technology as a distraction or detraction from learning. 
Lack of technical support

Student expectations

Technology as Distraction? (8)

Technology as disrupting human relationships, interaction (3)

Difficulty of staying current (2)

Detracting from learning (4)

Tech doing social damage (2)

\section{Figure 6. Barriers to Integration of New Tools}

Clear "technical difficulties" experienced in the past influences faculty's willingness to engage with newer tools in the present. Faculty described platforms not working in the moment, a lack of support from the technology support team at the university, poor Internet Connections, and inadequate learning management system that the school used, and lack of storage capacity. The difficulty of staying current was echoed multiple times, and one professor questioned if it was worth even trying to, since young people react poorly to school appropriation of their tools:

I would say that I've noticed that ironically email is read less and less and I'm thinking Oh God do we have to assign stuff on Snapshot now? But you know as soon as we do that like bacteria they're going to become resistant to Snapchat. .. they are going to hate us . . as soon as we do, it's no longer cool.

Clearly, then, others placed the blame, not on the tools or support teams, but on the students themselves. A biology professor explained:

It's difficult . . we weren't taught that way, students expect a certain thing when they come to a biology class ... to sit down and be talked at and then maybe they'll pick up the book at some point and two days before the exam they will re-read their notes and they expect that to work for them and it won't.

Multiple faculty alluded to this issue, arguing that students prefer printed text over e-text, that students don't enjoy open ended inquiry and prefer more traditional school structures. A physics professor shared the story of his own experience flipping the classroom 
Professor: [Flipped classrooms] didn't work for introductory level course. . . Because they revolted, essentially... And, you know, and I went to the Dean, and said you know, I can't remember the exact words I used, I said you know I'm essentially stealing their money by going back to lecture. Because ... you know, one of them was 'Dr. ___ clearly doesn't know how to teach. This is a teaching institution, not a research institution. He should leave and go find another [job]."

Because I was like, you know, it's like this is the best offering of any class I've ever given at Millsaps, and- 1 ] essentially [got] negative credit, right?

Despite the fact that learning levels clearly improved using this tech-mediated approach, students felt differently. He bemoaned: “*Smith students don't like flipped classroom. They don't like it because they think their professors should be the one should hold all the knowledge- because that's the illusion of professor-dom ... and I can just sit back and be funny."

These kinds of student attitudes weren't only experienced in the sciences. A professor in the history department noted: "Students don't know how to use [online] maps and have done nothing. I gave them an assignment for 8th graders and almost none of the students could do any of it and were very resistant to it as well." A studio arts professor remarked: “They don't like being told that they have to google things, but it's part of living in the 21 st century. When a student emails me a googleable question, you know how aggravating that is, it's the worst."

Note that nearly all of the concerns discussed above by faculty were situated at various corners of TPACK rather than at the nexus points. Professors feared student attitudes towards new tools and their lack of knowledge in working with them. There was also an existential fear about "keeping current" and the fact that reappropriating newer tools for classroom purposes causes them to lose their allure. But concerns about student interest in shifting pedagogical approaches and tools were not the only reason that faculty took pause before bringing technology into the classroom. Others had more practical considerations around distraction that did begin to encompass thinking around technology, pedagogy, and content. One faculty member explained:

Also, then they're going to have to get out their cell phones and that's going to be a bit harder to police like "you can have your cell phone now and then you're going to have to put it away" ... and now you have to get it back out again. And now there's an element. . nothing's going to stop them from typing in "PENIS."

Technology as distraction was a theme that emerged spontaneously during eight separate faculty interviews. When I asked one professor how they think about technology in their classroom space, she remarked:

For the most part I find technology to be an enormous distraction. Phones, phone addiction, I had them do a technology fast for $24 \mathrm{hrs}$. and only if they had to do an assignment, then they could do that. I ask students to put technology away on a daily basis and by mid-semester they start to realize to put it away at class start.

While these same professors did acknowledge that tech tools could provide affordances (for instance, looking up information needed in the moment), they stood firm that the general result of newer tools had even larger pitfalls. One religious studies professor used the scenario of a student using a phone in "a totally exemplary way" to illustrate his point: "So this wonderful student who had excellent attitude about the class would disappear down the rabbit hole [looking down at his phone] the way you do because one thing leads to another." He used this very story of the exemplary student Journal of the Scholarship of Teaching and Learning, Vol. 19, No. 2, March 2019. josotl.indiana.edu 
to introduce the absolute ban of technology in his classes which enabled him to "assume the best" of his students and "stay positive".

A professor in the psychology department defended her reluctance on allowing students to have new media out, not merely on students getting distracted, but on her own tendency to lose focus:

So I have a new rule this year where they are not allowed to have their phones out. They have to put them away and I got this from [a colleague] because I previously just had a rule like "oh no texting in class" but then we were always just looking at our phones casually or pushing the buttons or if you see you have a text it's really hard . . you're thinking about it . . And really the reason I have it is not just because I need to be the center of attention because obviously that's part of it, but also because I'm also such a distractible person myself and so I joke about it but literally this is how my brain goes. If I see somebody else texting I think to myself "I wonder if I have a text- I wonder if I should check my phone. I wonder if they're trying to make plans for later today. Do I have plans for later today? What am I doing for dinner? Am I getting dinner?" My brain starts spiraling because I'm so tangential with everything I do and everybody in my class knows I get off on these crazy whatever things . . . I think it's part of my CHARM and this is what I continue to tell myself so I don't want them to have the technology in class...

While for many professors, barriers to using technology was a matter of practicality and managerial control, others felt conflicted by their perception of technology as inherently detrimental to learning and class relationships. One theater professor spoke passionately against the ways that new media might erode authenticity:

More and more and more and, yes I'll talk about online dating and the rest of it- you try to package and plan and so once it comes to actually relating to another human being you've already edited and Photoshopped everything so that once you're in front of another human being you don't have to do anything. . . The danger is that when people lose their ability to trust themselves and their ideas without the digital.

A political science professor asserted: "Even though social media, Twitter, Facebook, all the other stuff that's out there, is supposed to make us feel more closely connected, I actually think it makes it less personal". Another professor remarked "And it is also part of what we sell as an institution, that you are here to have interaction with, with, with your professors, you are not here to, to have an online experience." Such a personalized face-to-face experience is perhaps epitomized in one particular room on campus which is known for not having any technology or Internet signal:

All of my best classes have been in CC5 which is the one room in the building that doesn't have any tech at all ... there could be some traction for the sanctuary from interconnectivity .. . because we definitely have the best discussions- kind of a dropped signal zone- there's just a mentality about being in that experience that we run with. It just feels like we are here to talk to each other and wrestle with ideas.

The fact that technology detracts from learning came up with four separate interviewees. One professor cited a recent study that had been widely touted around campus, explaining: "I also encourage them to handwrite their notes instead of typing them on their computers. There's a lot of research that says it's better for memory attention, for engagement, for mindfulness and so that is what I encourage." Others questioned the efficacy of flipped classrooms or online classes and the Journal of the Scholarship of Teaching and Learning, Vol. 19, No. 2, March 2019. josotl.indiana.edu 
ease of cheating, and one faculty member put it quite simply: "I'm skeptical of [technology's] effectiveness."

It is notable that around half of my interviewed professors who were reluctant to embrace newer tools into learning spaces made claims well-informed by a cluster of technological, pedagogical, and content knowledge. They fear, for instance, that technology will distract students from the content and from full engagement in the pedagogical activities planned. But there were also many other faculty members operating in the same nexus that came to alternate conclusions, the subject of the next section.

\section{Affordances of New Tools}

While it is clear from the previous section that many faculty members were reticent in their incorporation of newer tools, the interviews also revealed a large portion of enthusiasm. Notably, the most positive interview comments around teaching with newer tools also emerged at the intersection of technology, pedagogy, and content knowledge. (See Figure 7.)

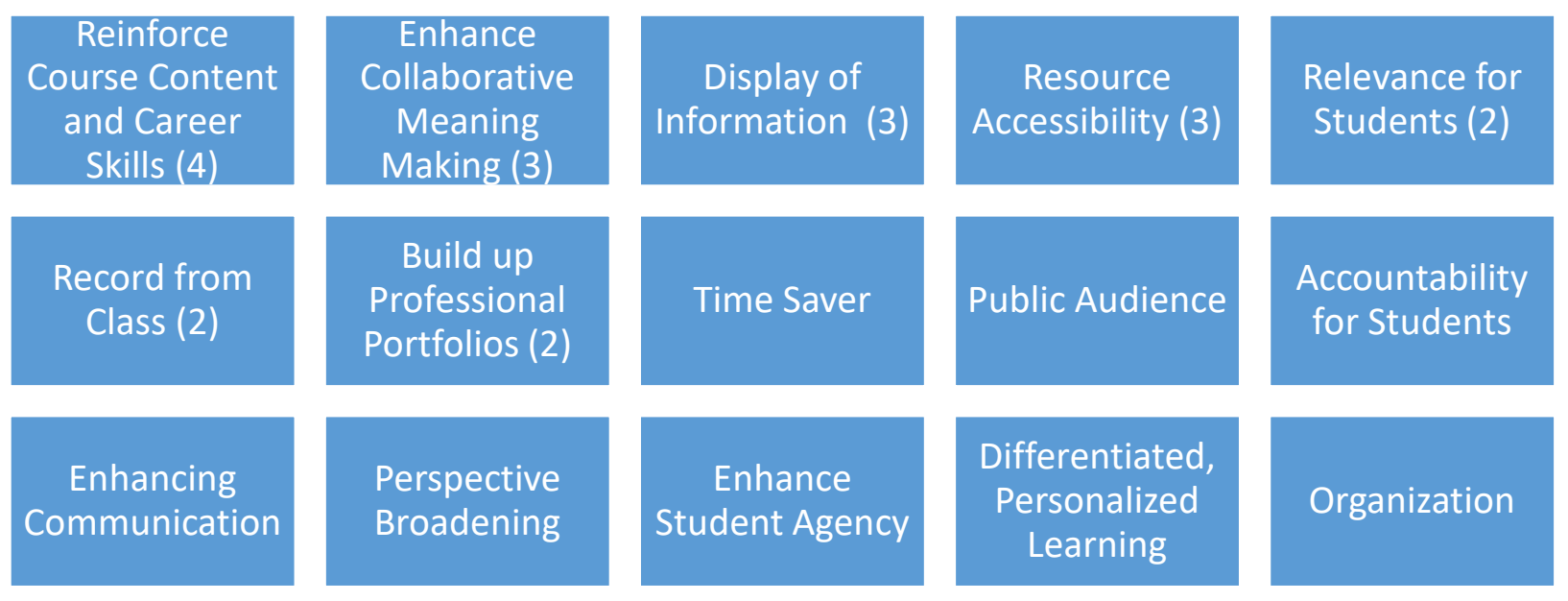

\section{Figure 7. Affordances of New Tools}

For instance, an art professor described one of her greatest successes the past semester ... asking students to blog before class and then using these blogs as a springboard into leading class discussion:

It's been really amazing . .. I realize I don't have enough time to prep . . . [there is] so much research of performance artists that you have to present- it's all about the lineage of performance artists- a safety net of students to understand you are not alone . . there are other artists, although it's a small population that are interested in their bodies, experimenting, this historic- it's so hugely important ... you can only show, do exercises. Each of [my students] present every week a research [blog] post and present to the class and prompt the discussionit's been really great for me as a teacher, I don't have to prep for that, and I'm familiar with all the artists they are showing. .

Note the dizzying array of TPACK negotations she makes. She begins with the practicallogistical issues of limited time, moves to the central purpose of content in that class (expose students to a wide range of performance artists to enhance their confidence in the art), describes the student- 
centered pedagogical move (have them post blogs and then present) which is supported through the multimodal nature of a newer blog tool, one that importantly enables students to embed video of the performance art. Other faculty members made similar moves, as they discussed the ways that newer tools unlocked access to a wider range of texts and materials for thinking and learning, aided in accountability and transmission of information, and enabled people to take agency over their own learning, just to name a few. Each time faculty delved into this nexus of pedagogy, content, and technology, the hyper-focus on the newer tool (quite present in the previous pessimistic section) faded into the background. For instance, in discussing the affordances of flipping the classroom for differentiation, a physics professor explained:

I mean, I think there's — and, and one reason I ended up doing the flipped and I know it's not, it doesn't have to be flipped, it's active learning in general, and flipped just works for me for a lot of different reasons. One is when I have really strong students, my goal long-term is to have a whole lot of courses flipped so that like when I have a student that's so strong he's able to finish this course two-thirds of the way through, just go ahead and give him the videos for the next semester. And, you know, I'll work out with the administration where to give him credit, right? But there's no reason to slow him down ..

On the other hand, three of the interviewed professors described usage of newer tools, not to promote one individual to jump ahead of the rest of the class, but to aid in collaborative meaningmaking or archiving. A history professor described her future goal to do some archiving and mapping with a collaboration of students across institutions. An English professor described his class involved in "Book Traces" which archives images of books to a consortium housed online. He went on to wax eloquently about the way that digital projects indeed demand collaboration:

the dissertation can seem like such a-in humanities_can seem like such a solitary activity. You know, you kind of go into your carol ... you don't have research sites . . . there's no field work, you know and like. I mean there can be ... and you conceivably, or presumably, you have these committee members ... But so much of it is so solitary and that translates in a certain way to the pragmatic question of making a career in our field. I mean unlike in the sciences where you might be a co-author with fifteen other people on a paper, you know, our, our tenured decisions are made by, you know, in part by publications that we produce in a kind of you know self-sustained way. But the digital humanities doesn't work like that; because I can't both know all the coding that I need to know to produce the experience for the user that I want, and know all of the research that I need to have, too-demands collaboration.

Similarly, a professor in anthropology discussed one of his favorite newest innovations to support their traditional text readings of ethnographies: asking students to submit to a Wiki a 30-45 second video "shot from the perspective of an east African viewer as opposed to CNN or BBC or something like" then used as a springboard into an in-class conversation.

In other words, when teachers in higher education shared successes with technology, they often foregrounded its affordances to promote better pedagogy and clearer mastery of content. However, professors did highlight the tool itself when it directly related to future career usage, such as when the art professor described the necessity for students to be able to build their own portfolio websites:

I got my degrees in sculpture, but as an artist you always had to manage your images and I had to build my own website, when you build applications you have to edit photos to be a Journal of the Scholarship of Teaching and Learning, Vol. 19, No. 2, March 2019. josotl.indiana.edu 
certain dimension and that's just alone means you has to touch a computer so it's not this magical thing that an artist would live away from a computer if you want to advance your career, you have to do applications you know.

Another practical emphasis in tool implementation emerged when this professor in business talked at length about FRED (Federal Resource Economic Data):

The other thing that has been incredibly helpful is that all of the macro data websites are really so good now, and when I said could you plot unemployment and the minimum wage, FRED at one point you had to download all that data into your Excel spreadsheet and then create, create your graph yourself. But within FRED, FRED has a graphing generator and if you just sort of want to know real quick what that relationship is you just tell it to plot and it has just a really nice tool within FRED that you see a lot of the PowerPoint presentation from the big guys they have, or the presentations that are online from the big guys, they have their basic data plots as a copy and paste from FRED. And so it's really cool to say look this is a tool that is so easy to use.' . . . Ten years ago the data was in there but it was clumsy to download it, sometimes you didn't download it correctly or it went to a different file or you could never tell where it went. And I'm still of the age that I use technology the way I use my car: I turn it on and I expect it to work and if it doesn't I call somebody else to help me with it. So FRED is pretty reliable in that I don't have to worry about whether FRED is going to work or not.

Note that her key concern resides around reliability and functionality for real world application, as opposed to trying out new media because it is shiny and new.

\section{Discussion: Toward Critical Digital Pedagogy}

In many ways, my findings illuminate the amazing consistency in beliefs around pedagogy, technology, and content across all disciplines at $*$ Smith College. Whether one teaches engineering or education, we must all reckon with what to do with the powerful machines sitting at our students' fingertips. But the findings also reveal that our most thoughtful educational design surfaces at the nexus of our knowledge around technology, pedagogy, and content, particularly when these knowledge bases interact with positive beliefs about the potential of new tools. The question, however, remains: what happens when negative beliefs around newer tools inhibits faculty interest in reimagining their teaching practices?

First it is key to recognize the healthy source of digital skepticism for many liberal arts faculty. Professors that I interviewed at *Smith College had a preoccupation with the human side of teaching, necessarily so. Our existence as a college depends upon persuading the world that small faculty to student ratios substantively change the quality of the educational endeavor. But while some faculty were able to make peace with the hybrid nature of teaching and living and making meaning in the $21^{\text {st }}$ century, faculty most concerned with new tools saw them as diametrically opposed toward their aims to connect with and empower young citizens. I argue that the call for technology integration should be replaced with an emphasis on critical digital pedagogy (Rorabaugh \& Stommel, 2012; Morris, 2017). Armed with this critical lens, faculty are encouraged to think deeply about the decisions they make in their classrooms, to "look askance at the tools we use," (Rorabaugh \& Stommel, 2012) whether they are digital or physical, and to have conversations with students about the affordances and limitations of every platform we use for making meaning.

Critical digital pedagogy takes the spotlight off of utilizing all things shiny and digital and new and helps us zoom out to the fuller picture, the one that takes into account the ebb and flow that Journal of the Scholarship of Teaching and Learning, Vol. 19, No. 2, March 2019.

josotl.indiana.edu 
make up our learning and communicating as humans. Increasingly, scholars are losing patience with long-held dichotomies such as play/learning, digital/physical, informal learning/formal learning (Pittman et al., 2004; Jewitt, 2008; Husbye et al., 2012). Learning is being recognized as operating on a vast network of diverse nodes, including communities, materials, teachers, technologies, and much more (Ito et al., 2013). Pete Rorabaugh and Jesse Stommel (2012) write in defining Hybrid Pedagogy that "all learning is necessarily hybrid," since we continually shunt back and forth screens and faces to communicate, make meaning, gather knowledge, and network. Morris (2017) explains:

The digital isn't magic. It isn't mysterious. It's regular human communication astride a new medium. Let me say that again: It's regular human communication astride a new medium. There's no need to make it more than it is. ... What is needed, what has always been neededsince the early days of videotaped lectures to the primordial ooze of the invention of the LMS [learning management system] - is an effective digital pedagogy that lets us span the interface, cross the digital, and find one another where we are.

TPACK, then, is useful as a frame for decision-making, only so far as it enables us to get to the destination to which our deepest beliefs around teaching/learning direct us. Transformative faculty members take the time to confront their own deeply held teaching beliefs, determine if they hold up under scrutiny, and then reflectively utilize their knowledge bases (content, pedagogical, and technological) to make a pathway forward.

\section{Appendix}

Appendix 1. Interview Protocol Questions for Faculty

- BACKROUND: What field(s) do you associate with? What job(s) are you preparing students for? How long How long have you been at the college?

- What do you think "preparing students for the 21st century" means in your particular discipline/ field?

- Follow up: (tie it to how they defined it)- Do you see yourself as preparing students for the 21 st century in your discipline? Why or why not?

- What technologies do you use with students in your classes? Which are most effective and which are least effective?

- What technologies would you like to use with students in your classes? (But don't b/c of time, access, training, etc?) Why don't you use them?

- Have you had any training for teaching with technology? If you could have training, what would it be?

- What sensibilities/dispositions/ways of thinking do successful people in your field need in 2016?

- Has there ever been a time when a new technology substantively changed the way you taught?

- Do you think skills/content needed in your field have changed in the last 20 years?

- What "old" skills/content/teaching approaches are still relevant in the 21 st century? Why?

- Do you allow students in class to use their own technology (laptop) for learning purposes? Why or why not and how?

- Do you find that technology is distracting for students in your classroom? How do you deal with that?

- What "digital citizenship" lessons do undergraduates need to learn to be successful? 
- Do you use social media to professionally represent yourself or to connect with students? (Twitter- Instagram/FB) In what ways/why or why not?

\section{References}

Anders, P. L., Yaden Jr, D. B., Da Silva Iddings, A. C., Katz, L., \& Rogers, T. (2016). Entanglements, Intensities, and Becoming: Non-Representational Perspectives on Literacy Research. Journal of Literacy Research. 48(1). 3-4.

Angeli, C., Valanides, N., \& Christodoulou, A. (2016). Theoretical Considerations of Technological Pedagogical Content Knowledge. Handbook of Technological Pedagogical Content Knowledge (TPACK) for Educators, 2nd Ed. 11-32.

Barnard, S. (2015 Sept). Building castles in the air: Critical digital pedagogy and the pursuit of praxis. Hybrid Pedagogy. Retrieved from http://www.digitalpedagogylab.com/hybridped/buildingcastles-in-the-air-critical-digital-pedagogy-and-the-pursuit-of-praxis/

Breneman, D. W. (2010). Liberal arts colleges: Thriving, surviving, or endangered? Brookings Institution Press

Brown, D., \& Warschauer, M. (2006). From the university to the elementary classroom: students' experiences in learning to integrate technology in instruction. Journal of Technology and Teacher Education, 14(3), 599-621.

Clark, B. R. (1992). The Distinctive College. Transaction Publishers, Department NRB93HE, Rutgers-The State University of New Jersey, New Brunswick, NJ 08903.

Corbin, J., \& Strauss, A. (2008). Basics of Qualitative Research: Techniques and Procedures for Developing Grounded Theory (3rd ed.).Thousand Oaks, CA: Sage.

Ertmer, P. A. (2005). Teacher pedagogical beliefs: The final frontier in our quest for technology integration?. Educational technology research and development, 53(4), 25-39.

Ertmer, P. A., \& Ottenbreit-Leftwich, A. T. (2010). Teacher technology change: How knowledge, confidence, beliefs, and culture intersect. Journal of research on Technology in Education, 42(3), 255-284.

Fairchild, J., Meiners, E. B., \& Violette, J. (2016). "I Tolerate Technology_I Don't Embrace It": Instructor Surprise and Sensemaking in a Technology-Rich Learning Environment. Journal of the Scholarship of Teaching and Learning, 16(4), 92-108.

Gee, J. P. (2014). An introduction to discourse analysis: Theory and method. Routledge.

Husbye, N. E., Buchholz, B., Coggin, L. S., Powell, C. W., \& Wohlwend, K. E. (2012). Critical lessons and playful literacies: Digital media in PK-2 classrooms. Language Arts, 90(2), 82-92.

Ito, M., Gutiérrez, K., Livingstone, S., Penuel, B., Rhodes, J., Salen, K., ... \& Watkins, S. C. (2013). Connected learning: An agenda for research and design. BookBaby.

Journal of the Scholarship of Teaching and Learning, Vol. 19, No. 2, March 2019.

josotl.indiana.edu 
Jewitt, C. (2008). Multimodality and literacy in school classrooms. Review of research in education, 32(1), 241-267.

Lohnes, S., \& Kinzer, C. (2007). Questioning assumptions about students' expectations for technology in college classrooms. Innovate: Journal of Online Education, 3(5), 2.

McQuiggan, C. A. (2007). The role of faculty development in online teaching's potential to question teaching beliefs and assumptions. Online Journal of Distance Learning Administration, 10(3), 1-13.

Mishra, P., \& Koehler, M. J. (2006). Technological pedagogical content knowledge: A framework for teacher knowledge. Teachers college record, 108(6), 1017.

Morris, S. (2017 May) Critical digital pedagogy and design. Retrieved from http://seanmichaelmorris.com/critical-digital-pedagogy-and-design/

Pajares, M. F. (1992). Teachers' beliefs and educational research: Cleaning up a messy construct. Review of educational research, 62(3), 307-332.

Pittman, K. J., Irby, M., Yohalem, N., \& Wilson-Ahlstrom, A. (2004). Blurring the lines for learning: The role of out-of-school programs as complements to formal learning. New Directions for Student Leadership, 2004(101), 19-41.

Rorabaugh, P. \& Stommel, J. (2012 June 13). Hybridity, Pt 3: What does hybrid pedagogy do?. Retrieved from http://www.digitalpedagogylab.com/hybridped/hybridity-pt-3-what-doeshybrid-pedagogy-do/. Hybrid Pedagogy.

Saldaña, J. (2015). The coding manual for qualitative researchers. Sage.

Spodark, E. (2003). Five obstacles to technology integration at a small liberal arts university. THE Journal (Technological Horizons In Education), 30(8), 14.

Umbach, P. D., \& Kuh, G. D. (2006). Student experiences with diversity at liberal arts colleges: Another claim for distinctiveness. The Journal of Higher Education, 77(1), 169-192.

Umbach, P. D., \& Wawrzynski, M. R. (2005). Faculty do matter: The role of college faculty in student learning and engagement. Research in Higher Education, 46(2), 153-184.

Zhang, J. (2010). Technology-supported learning innovation in cultural contexts. Educational Technology Research and Development, 58(2), 229-243. 